\title{
DRAFT
}

The growth of apprenticeship in England: Doubts beneath the numbers

By Professor Alison Fuller, UCL Institute of Education

Eyebrows were raised when George Osborne, the UK's Conservative Chancellor of the Exchequer, recently announced the introduction of a statutory apprenticeship levy ${ }^{1}$. Why was a Conservative administration bringing in an interventionist labour market measure, and direct cost on employers? On the face of it, implementing a levy would have been much less surprising coming from a Labour government. However, the use of apprenticeship as an instrument of public policy in England is not new; it has been a feature of successive governments whatever their political colour. In this article, I will provide an overview of this history, highlighting the ongoing tension between quality and quantity within the government-supported apprenticeship programme, and the policy reforms which help explain its expansion. I will argue that successive governments' decisions to extend the parameters of what 'counts' as apprenticeship is an important part of the explanation.

\section{Historical overview}

In the 1960s approximately one third of young male school leavers entered an apprenticeship ${ }^{2}$ (Mirza Davies 2015). However, during the period of industrial decline and rising unemployment in the late 1970s and 80s, the availability of apprenticeships decreased. Liberalisation of the economy as a free market response to rapid industrial and technological change, and policy decisions such as the abolition of the statutory industry training boards reinforced the UK's traditionally laissez faire approach to training and skill development and contributed to the depletion of the country's capacity to train. This period is associated with a dramatic rise in youth unemployment, and the introduction of government supported training schemes for school leavers who couldn't find jobs. A critical literature developed that focused on the shortcomings of these schemes, identifying their limitations as vehicles for providing high quality skills training and articulating concerns that participants were simply being 'warehoused', or were moving in and out of programmes through a 'revolving door', rather than finding sustainable jobs (inter alia Raffe,1987; Lee et al 1990).

\footnotetext{
${ }^{1}$ The announcement was made in the Summer Budget of 2015 and the Autumn Statement 2015 stated that it would be introduced in April 2017 see the following link for details; https://www.gov.uk/government/publications/apprenticeship-levy/apprenticeship-levy

2 James Mirza-Davies, 9 March 2015 https://commonslibraryblog.com/2015/03/09/a-short-history-ofapprenticeships-in-england-from-medieval-craft-guilds-to-the-twenty-first-century/
} 
By the early 1990s, as the economy and employment rates improved, the political and economic discourse became focused on national (un-)competitiveness and the challenge of competing more effectively in an increasingly globalised economy (DTI 1998). Low productivity, and skills deficits in the intermediate or technician level of the labour market were highlighted as areas of weakness compared with key industrial rivals such as Germany (Mason and van Aart 1990, Prais et al 1995).

In 1993 the then Conservative government (with John Major as Prime Minister) decided to address the intermediate skill gap by announcing the 'Modern Apprenticeship' (Fuller and Unwin 2003a). The new apprenticeships would be available not only in traditional craft and manufacturing occupations but also in the rapidly expanding service sector. Moreover, the initiative included an explicit commitment to equity and diversity, particularly in terms of increasing the number and proportion of females, those from black and minority ethnic backgrounds, and those with disabilities (Fuller and Unwin 2009).

Unlike previous youth training schemes which had primarily delivered training at basic or semiskilled level (referred to as Levels 1 and 2 respectively in the UK's National Qualifications Framework), the Modern Apprenticeship was designed to produce skilled workers at Level 3. The initiative was presented as a measure that would produce a more highly skilled workforce and hence contribute to improved productivity and competitiveness (Gospel and Fuller 1998). Since the pilot phase of the Modern Apprenticeship in 1994-95, the programme has grown from approximately 75,000 registrations (known as 'starts') a year to around half a million a year (Delabarre 2015). This expansion has been supported by successive governments and political parties across the political spectrum. However, the country's relatively flexible labour market together with an historically voluntarist approach to training and skills, raises the intriguing question of how this growth has been achieved.

\section{Explaining the growth of apprenticeships in England}

Part of the explanation for the expansion of apprenticeships, is that it has been a priority for successive governments. Over the years since the Modern Apprenticeship was introduced, Ministers from Conservative, Labour and Coalition governments have all been keen to celebrate their particular administration's success in creating more apprentices. Numerical target setting has played an important role, with the latest being the current government's drive to create 3 million apprenticeships by 2020 (BIS 2015). Beyond this, a range of mechanisms, including major shifts in the parameters of what counts as a government supported apprenticeship, have been instrumental in the programme's expansion and delivering 'the numbers'. 
First, the original positioning of Modern Apprenticeship as a Level 3 programme focusing on the creation of skilled (as opposed to entry or semi-skilled) workers was fundamentally changed in 2001. At that point a basic training programme, known as National Traineeship (NT), was rebadged as Foundation Modern Apprenticeship (FMA), and the higher level Modern Apprenticeship was rebranded as Advanced Modern Apprenticeship. At a stroke this brought all those young people participating in the lower level NT scheme into the apprenticeship programme. Second, although the Modern Apprenticeship was originally only available to young adults aged up to 24 years old, from 2005-06 the upper age limit was removed and it became an all age-programme (Fuller and Unwin 2009, Fuller et al 2015).

Third, a change in funding arrangements effectively allowed a scheme known as 'Train to Gain' to become part of the government supported apprenticeship programme. Train to Gain was introduced in 2006 by a Labour Government as a work-based programme designed to enable adult employees to gain certification for their skills. Critical evaluations of the programme (e.g. Ofsted 2008) pointed to considerable deadweight and questions about whether employees were actually learning any new skills (Fuller and Unwin in press), and the programme was withdrawn in 2010-11. Given that in practice there was little substantive difference between the requirements and delivery arrangements for Train to Gain and apprenticeship, particularly at the lower level, it was relatively easy for providers to switch participation from the former to the latter programme. These decisions led to a significant growth in take up by those aged 25 plus and in registrations on the lower semiskilled level programme.

Fourth, growth has also been achieved by allowing individuals already in employment (often for many years) to be registered in an apprenticeship linked to their current job role. This means that many apprentices particularly those aged 25 or over are already in a job when they are 'converted' into becoming apprentices. In 2008 it was revealed in the Department of Innovation, Universities, Science and Skills Committee, that approximately 70 per cent of apprentice starts were conversions. Survey data suggests that the 'conversion rate' in some sectors such as Health and Social Care, where older apprentices dominate, is as high as $90 \%$. Fifth, in 2009-10 the programme was extended again, this time to provide higher level apprenticeships (Level 4 plus in the National Qualification Framework - see below).

Sixth, the way funding of apprenticeship has been organised and distributed has also had a major influence on apprenticeship take up. At its simplest, the apprentice's wages are paid by his or her employer, whilst the programme's funding pays for the costs of the training and associated credentials. The public funding element is routed, via the 'Skills Funding Agency' (SfA), to registered 
training providers rather than directly to employers ${ }^{3}$. The agency contracts with and funds providers to 'deliver' an agreed number of apprenticeships within a set time period. This model incentivises providers to achieve their numerical targets for registrations and completions, and has contributed to the skewing of registrations a) to the quicker to complete lower level apprenticeships, and b) to programmes in sectors where it is easier and cheaper to achieve successful completions (Wolf 2015).

In a bid to increase the number of apprentices in the under 25 age group and the involvement of small employers with fewer than 50 employees, the government introduced grants of $£ 1500$ per apprentice (up to a maximum of five per employer) in 2014. The number of apprentices in this age category has increased from 120,000 (2013-14) to 126,000 starts (2015-16) (see Table 1 below). Most recently (from April 2016), as a further measure to incentivise take up by young people the government has removed the requirement for organisations to pay the employers' national insurance contribution on any apprentice aged under the age of 25.

Taken together, initiatives to include lower level schemes (such as the NT and Train to Gain), and to allow existing employees to convert into apprentices have loosened the parameters of what counts as apprenticeship and help explain the growth of the government supported programme in England.

\section{Numerical snapshot}

So, what does the current apprentice population look like? The following figures provide a numerical snapshot of apprenticeship 'starts' in England in 2014-154. In contrast to the traditional perception of apprentices as young school-leavers, Table 1 confirms that in England it is the 25 and overs that make up the largest group, with the under 19s the smallest. Much of the increase in the 25 plus age group happened from 2010-11 after the withdrawal of the Train to Gain Initiative with a jump in the number of starts from 49,100 in 2009-10 to 182, 100 in 2010-11. The number of young people (under 19) starting an apprenticeship each year has ranged between approximately 100,000 in the early 2000 s to 126,000 in 2014-15. These figures mean that approximately 6 per cent of all 16 to 18 year olds in England begin an apprenticeship programme. At the other end of the age scale, there were over 3,400 starts by people aged over 60 in the 2014-15 (Fuller et al 2015)

\footnotetext{
${ }^{3}$ For more details about funding arrangements see https://www.gov.uk/take-on-an-apprentice/overview

${ }^{4}$ See the government website https://www.gov.uk/government/statistical-data-sets/fe-data-libraryapprenticeships for details of and trends in the apprenticeship statistics.
} 
Table 1: Apprenticeship 'starts' by age (England 2014-15)

\begin{tabular}{|l|c|c|}
\hline Age group & Number & \% of all starts \\
\hline Under 19 & 126,000 & 25 \\
\hline $19-24$ & 160,000 & 32 \\
\hline 25 and over & 214,000 & 43 \\
\hline All & 500,000 & 100 \\
\hline
\end{tabular}

Table 2 presents the number and percentage of starts by Level. As indicated above, apprenticeship is available at various Levels within the National Qualification Framework. The formal credentials available at each Level of the programme are loosely benchmarked to the nearest equivalent general educational qualification. Hence, those accredited at Level 2 obtain qualifications broadly equivalent to GCSEs, the educational awards young people are expected to attain at 16; while those accredited at Level 3 obtain qualifications broadly equivalent to $\mathrm{A}$ levels, the awards young people following the academic track can achieve at age 17-18 after two years of post-16 full-time study. Those pursuing Higher Apprenticeships (at Level 4+) include programmes which provide credentials broadly equivalent to successful completion of the first or second year of a bachelor degree (Level 4 and 5 respectively).

The majority of apprentices register in the lowest level of the programme (Level 2), which is associated with training for semi-skilled rather than skilled jobs. In recent years, there has been a welcome policy push to open up apprenticeships at higher levels and to promote apprenticeship as an alternative route to university with parity of esteem. Although the numbers are relatively small, they are growing in occupations such as accountancy, management and engineering.

Table 2: Apprenticeship 'starts' by level (2015)

\begin{tabular}{|l|l|c|}
\hline Level & Number & \% of all starts \\
\hline Level 2 & 298,000 & 60 \\
\hline Level 3 & 182,000 & 36 \\
\hline Level 4+ & 20,000 & 4 \\
\hline All & 500,000 & 100 \\
\hline
\end{tabular}


Finally, Table 3 provides a breakdown of the top 10 sectors in terms of popularity. Whilst in total there are over two hundred apprenticeship sectors, the top 10 account for two thirds of all starts. As the table shows the majority of starts are in service sectors, with 'Health and social care' being (by far) the most highly populated. The traditional skilled apprenticeship sectors of 'engineering' and 'construction skills' appear in $8^{\text {th }}$ and $9^{\text {th }}$ place respectively. The dominance of apprenticeships in the service sectors helps to explain why females account for over half of all starts (53\%). Whilst the broad gender balance in apprenticeship participation is welcome, females take up of traditionally male occupational areas such as engineering, construction and plumbing still makes up less than $5 \%$ of registrations. Similarly, males are strongly under-represented in traditionally female sectors such as child care and early years (Fuller and Unwin 2014a).

Table 3: Top 10 sectors for starts

\begin{tabular}{|l|l|}
\hline Sectors & Number \\
\hline Health and social care & 85,000 \\
\hline Business Administration & 49,000 \\
\hline Management & 43,000 \\
\hline Hospitality and catering & 32,000 \\
\hline Customer service & 31,000 \\
\hline Children's care, learning and development & 22,000 \\
\hline Retail & 18,000 \\
\hline Engineering & 18,000 \\
\hline Construction skills & 17,000 \\
\hline Industrial applications & 14,000 \\
\hline Total & 329,000 \\
\hline
\end{tabular}

\section{Apprenticeship as a learning journey or lever of public policy?}

Since medieval times, the term "apprenticeship" has been used to describe the journey a person takes from novice to expert in a specific occupational field. The concept transcends occupational boundaries and hierarchies, and is used by surgeons and barristers as well as engineers, carpenters, chefs, actors and musicians. However, in terms of its location in diverse national systems of vocational education and training, apprenticeship is traditionally positioned as creating skilled or intermediate/middle level employees for the labour market - it's seen as a pathway to skill formation above that required for competence in semi-skilled jobs and below that required for graduate level employment. This means that, in theory, its additionality is linked to the role it plays 
in creating productive skilled workers for the labour market, and providing individuals with access to the kinds of jobs that offer a platform for career progression and socio-economic mobility.

Traditionally, and in line with conventional human capital theory, apprentices are low paid in the early stages to offset their lack of productivity and training costs. As their knowledge and skills increase they become more productive (whilst remaining relatively low paid), helping employers to recoup their investment before the apprentice graduates to skilled worker wage rates at the end of their programme. It is worth remembering, then, that apprenticeship can first and foremost be understood as a model of learning for skilled work or occupational expertise, as such it is strongly associated with generating additionality - skills that would not have been created without this investment.

The public perception of apprenticeship in the UK and Europe, and probably in the US too is of a young person, probably fresh out of high school becoming, for example, an apprentice electrician or chef. They are a novice and there's a lot to learn before they can view themselves or be viewed by employers as skilled and expert, or achieve credentials that have labour market currency and recognition. The training and development takes time and completion of the apprenticeship provides a solid platform for future progression. However as mentioned earlier, in England, about $70 \%$ of those registering on a government supported apprenticeship are existing employees who have been 'converted' into apprentices. Rather than being a vehicle for creating significant and different occupational expertise, participation for them mainly involves having their existing skills certificated (Fuller et al 2015). The amount of new learning is limited and opportunity for progression is constrained. On completion of the apprenticeship they are usually still in the same job and on the same pay. This approach means that apprenticeship generates a more qualified workforce, with numerical targets achieved, but the investment has not necessarily produce much additionality.

The availability of a mechanism that enables employees to have their skills certificated is positive. Many individuals, particularly older adults have previously not had the opportunity to have their expertise formally validated. The recognition of prior learning has long been seen to have an empowering and motivating effect, giving people the confidence to raise their aspirations and pursue further and higher level qualifications (e.g. Moore and van Rooyen 2002, NIACE 2013). All workers should expect to receive the training they need in order to be able to do their jobs, including access to induction when they are first recruited. The debate in England is around whether it is appropriate to count this range of practices as part of the government supported apprenticeship 
programme, or whether they should be facilitated solely by their employers or through alternative publicly funded schemes.

It is really important to note that there are examples of world class apprenticeships in England, particularly in sectors such as engineering which are more likely to recruit young people, using apprenticeship to develop them from novices to becoming competent engineers. This is a lengthy and comprehensive process, that costs employers much more than they receive in public subsidy (Hogarth et al 2012).

However, when you look more closely at the reality of the programme, it is hard not to conclude that whilst there are examples of excellent practice, the same cannot be claimed about the quality of the English apprenticeship system as a whole. Why is this? In my view, the answer relates to the core identity of apprenticeship as a model of learning being replaced by that of a policy instrument that can be endlessly tuned and retuned to deliver the numbers and fulfil diverse goals. The term 'apprenticeship' is being treated as elastic and unfortunately, this approach has too often been at the expense of quality (Ofsted 2015).

A core insight here is that the English model is essentially an assessment, rather than a learning-led programme. This relates to the legacy of competence-based National Vocational Qualifications (NVQs) as the mandatory output of from all government funded training programmes since the 1980s, and including apprenticeship since their introduction in the mid-1990s (Fuller and Unwin 2009). Central to the competence-based approach is the separation of the process of training (and vocational knowledge) from the assessment of competence. The use of competence-based qualifications, largely facilitated through the use of NVQs, in apprenticeship has meant that it is possible (and certainly at Level 2) for an individual to complete an apprenticeship largely through having their existing competences accredited, with very little new training involved. This also raises questions about the extent to which take up of apprenticeship is demand-led. A recent survey for the Department of Business, Innovation and Skills showed that (only) 'six in ten employers were aware that the training they had provided was an Apprenticeship, which fell to around four in ten (37\%) of those who had drawn their apprentices from existing staff' (Colahan and Johnson 2014, p. 7).

So what has research told us about what works: what makes a great apprenticeship? Well my colleague Lorna Unwin and I have developed the concept of the expansive - restrictive continuum which can be used as a tool by employers and providers to analyse their provision and how it can be moved further towards the expansive end (Fuller and Unwin 2003b, 2004, Fuller and Unwin 2014b). We argue that every workplace can be analysed to see where it sits on the continuum. At the 
expansive end, we find employers (of all sizes in all sectors, public and private) who understand that apprentices need to be afforded a dual identity as workers and learners for the duration of their training. A key feature of what we have called 'expansive apprenticeships' is that they provide a solid platform for progression to further or higher education and, or the next step of the relevant occupational career ladder. In restrictive environments, apprentices are moved as quickly as possible to being productive workers. The primary goal of all workplaces (including education and training institutions) is to produce goods and services, but the expansive workplaces try to ensure that shortterm production pressures do not harm the longer-term goals of both the organisation and the individual.

Our research shows that many apprentice employers want to provide good quality programmes but, particularly, those who have not got a long tradition of offering apprenticeships lack training capacity and knowledge about how to do it well, so they need help. And this is an area in which policy could invest and play a positive role in supporting employers, and in facilitating the development of collaborative approaches. Government surveys tend to report good levels of apprentice and employer satisfaction with apprenticeship (Colahan and Johnson 2014, BIS 2016). Whilst this evidence should not be discounted, it can be tempered by evidence from other sources such as Ofsted (2015), the official national inspectorate, whose recent survey identifies weak apprenticeship provision.

It is often small and medium-sized employers who find apprenticeships challenging, and who are concerned about their ability to support apprentices and provide them with opportunities to develop the full range of skills. Group Training Associations can provide an effective response to this. This is where employers with skill needs in similar occupations come together to work with a specialist provider, often with specialist training facilities and trainers to co-design the programme, and to ensure that all apprentices in the scheme get access to high quality training, creating and adding to a pool of skilled labour in which employers trust and can access (Fuller, Unwin and Weatherly 2015).

Finally, we've found that apprenticeship provides a really good window into the health of workplaces. Where apprenticeship is done well, you tend to find there's good training and development in place for the whole workforce, well-designed jobs, higher levels of employee involvement and discretion, stronger productivity, opportunities for career progression and that the goals of organisational and individual development are aligned. 


\section{The levy and final remarks}

This article started by referring to the government's recent radical announcement of an apprenticeship levy. We know that the levy will be introduced in April 2017 and will be constituted as a $0.5 \%$ levy on annual payroll over the first three million pounds of an employer's pay bill ${ }^{5}$. The accumulated fund will be accessible to small employers who are not liable for the levy as well as to those paying in. The government estimates that the levy will generate $£ 3$ billion pounds of benefits a year, with $£ 2.5$ billion to be spent in England ${ }^{6}$. Currently the government spends approximately $£ 1.5$ billion a year on apprenticeship. Beyond these details, information about how the levy will be implemented and how it will operate in practice are still sketchy.

For the government, the levy initiative appears attractive for two main reasons. Firstly, it will significantly increase employers' financial contribution to apprenticeship significantly growing the total amount of funding available for apprenticeship, while enabling the government to reduce public investment. Secondly, it should encourage more employers who are large enough to pay the levy to get involved in apprenticeships so that they can recoup at least part of their payment, as well as small employers who will be able to benefit from the funding made available to them from the total levy pot collected each year. Increasing employer demand for training has been a longstanding challenge in the UK (Keep and Mayhew 1996, Keep 2006), and helps explain why the current government has decided to introduce a statutory apprenticeship levy (see also Wolf 2015). If the initiative increases the number and percentage of employers engaging with apprenticeship, this will be seen as an important indicator of the policy's success. Currently only 15 per cent of employers have apprentices in England compared to 24 per cent in Germany (BIS 2015).

What is less clear is if, and how the levy will improve quality across the system. I would argue that the quality dimension will continue to be a cause for concern until apprentice learning and skill formation is put at the heart of the model. The UK is ranked lower than competitors such as Germany, France and the US ${ }^{7}$ for productivity, with relatively weak skills at the intermediate level being one of the reasons for this. The government expects the levy to expand apprenticeship as an important and positive policy response to this challenge. This is a worthwhile policy aspiration. When done well, apprenticeship can significantly enhance the skills and life-chances of individuals as well as having economic benefit for the employer. Following a government commissioned review of

\footnotetext{
${ }^{5}$ https://www.gov.uk/government/publications/apprenticeship-levy-how-it-will-work/apprenticeship-levyhow-it-will-work

${ }^{6} \mathrm{http} / / /$ researchbriefings.files.parliament.uk/documents/SN03052/SN03052.pdf

7 ONS Statistical Bulletin, International Comparisons of Productivity - Final Estimates, 2012, 20

February 2014
} 
apprenticeship, a major reform initiative has been introduced with the aim of raising quality through the creation of new employer-led apprenticeship standards (known as Trailblazers). Small numbers of apprentices are now enrolling on the new standards but it is too early to know the impact on quality these will have.

The English experience indicates that expanding the range of activities and schemes that count as apprenticeship is an effective strategy for achieving numerical targets and also lead to more employers participating in the programme. However, generating apprenticeships that deliver much needed national productivity gains, as well as providing all apprentices with high quality and substantial skill formation, and a strong platform for career and wage progression is (even) more of a challenge.

\section{References}

BIS (2015) English Apprenticeships: Our 2020 vision, BIS/15/604, London: Department for Business, Innovation and Skills

BIS (2016) Apprenticeships Evaluation 2015: Learner Summary Report, BIS Research Paper No. 287, London: Department of Business, Innovation and Skills.

Colahan, M. and Johnson, C. (2014) Apprenticeship Evaluation: Employers, Research Paper No. 204, London: Department of Business, Innovation and Skills

Delabarre, J. (2015) 2015 www.parliament.uk/briefing-papers/SN06113.pdf London: House of Commons Library

DTI (1998) Our Competitive Future, White Paper, London: Department of Trade and Industry

Fuller, A. and Unwin, L (2003a) Creating a 'Modern Apprenticeship': A critique of the UK's multisector, social inclusion approach, Journal of Education and Work, Volume 16, Issue 1, pp. 5-25

Fuller, A. and Unwin, L. (2003b) Learning as Apprentices in the Contemporary UK Workplace: creating and managing expansive and restrictive participation, Journal of Education and Work, Vol. 16 , issue 4,pp. 407-426

Fuller, A. and Unwin, L. (2004) Expansive Learning Environments: Integrating Organisational and Personal Development, pp. 126-144, 2004, in H. Rainbird, A. Fuller and A. Munro (eds) Workplace Learning in Context, London: Routledge

Fuller, A. and Unwin, L. (2009) Change and continuity in apprenticeship: the resilience of a model of learning, Journal of Education and Work, Volume 22, Issue 5, November 2009, pages 405-416 
Fuller, A. and Unwin, L. (2014a) The challenges facing young women in apprenticeships, in I. Schoon and J. Eccles (eds) Gender differences in aspirations and attainment: a life course perspective, p-. 182-200, Cambridge: Cambridge University Press

Fuller, A. and Unwin, L. (2014b) Creating and supporting expansive apprenticeships: a guide for employers and providers, National Apprenticeship Service

http://repository.excellencegateway.org.uk/fedora/objects/etf:1712/datastreams/RESOURCE/conte $\underline{\text { nt }}$

Fuller, A., Davey, G. Leonard, P., and Unwin, L. (2015) Does Apprenticeship Work for Adults? London: University College London, Institute of Education http://www.nuffieldfoundation.org/sites/default/files/files/Adult\%20Apprenticeship.pdf

Fuller, A., Unwin, L. and Weatherley (2015) Co-producing Expansive Vocational Education and Apprenticeship: A Relational Approach, pp. 16-26, Key Issues for Education and Training, UCL Institute of Education

Gospel, H. and Fuller, A. (1998), The Modern Apprenticeship: new wine in old bottles?, Human Resource Management Journal, Vol. 8, Issue 1, 5-22

Hogarth, T., Gambin, L., Winterbotham, M., Baldauf, B., Briscoe, G., Gunstone, G. Hasluck, C., Koerbitz, C. and Taylor, C. (2012) Employer Investment in Apprenticeship and Workplace Learning, BIS Research Paper No. 67, Department of Business, Innovation and Skills: London Lee, D., Marsden, D., Rickman, P and Duncomb, J. (1990) Scheming for Youth, Buckingham: Open University Press

Keep, E. (2006) State control of the English education and training system—playing with the biggest train set in the world. Journal of vocational education and training 58.1, 47-64.

Keep, E. and Mayhew, K. (1996) Evaluating the assumptions that underlie training policy, in Booth, AL and Snower, DJ, Acquiring Skills. Market Failures, Their Symptoms and Policy Responses, Cambridge: Cambridge University Press.

Mason, G. and van Ark, B.1994) "Vocational Training and Productivity Performance: An Anglo-Dutch Comparison", International Journal of Manpower, Vol. 15 Iss: 5, pp.55-69

Moore, A. and van Rooyen, L. (2002) Recognition of Prior Learning as an integral component of competence-based assessment in South Africa, South African Journal of Education, Vol. 22, 4, 293296.

Niace (2013) Using the Recognition of Prior Learning (RPL) within the Qualifications and Credit Framework (QCF), Leicester: NIACE 
Ofsted (2015) Apprenticeships: developing skills for future prosperity, No. 150129, download available at

https://www.gov.uk/government/uploads/system/uploads/attachment_data/file/469814/Apprentic eships_developing_skills_for_future_prosperity.pdf

Prais, S. J., Valerie Jarvis, and Karin Wagner. 1989. Productivity and vocational skills in services in Britain and Germany: Hotels. National Institute Economic Review, no. 130 (November): 52-74.

Raffe, D. (1987) The Context of the Youth Training Scheme: an analysis of its strategy and development, British Journal of Education \& Work Vol. 1, Iss. 1, 1987, 1-31

Wolf, A. (2015) Fixing a broken training system: The case for an apprenticeship levy, London: Social Market Foundation 